\title{
Ontogenetic Development of Cardiac Tolerance to Oxygen Deprivation - Possible Mechanisms
}

\author{
B. OŠŤÁDAL ${ }^{1,2}$, I. OŠŤÁDALOVÁ ${ }^{1,2}$, F. KOLÁŘR $\check{R}^{1,2}$, Z. CHARVÁTOVÁ ${ }^{1,2}$, I. NETUKA $^{1,3}$ \\ ${ }^{1}$ Center for Cardiovascular Research, ${ }^{2}$ Institute of Physiology, Academy of Sciences of the Czech \\ Republic, ${ }^{3}$ Institute for Clinical and Experimental Medicine, Prague, Czech Republic
}

Received October 3, 2009

Accepted October 30, 2009

\begin{abstract}
Summary
Our present focus on the hypoxic immature heart is driven by clinical urgency: cyanotic congenital cardiac malformations remain the single largest cause of mortality from congenital defects and ischemic heart disease is no more the disease of the fifth and older decades but its origin as well as risk factors are present already during early ontogeny. Moreover, the number of adult patients operated for cyanotic congenital heart disease during infancy steadily increases. This group approaches the age of the rising risk of serious cardiovascular diseases, particularly ischemic heart disease. Experimental results have clearly shown that the immature heart is significantly more tolerant to oxygen deficiency than the adult myocardium. However, the mechanisms of this difference have not yet been satisfactorily clarified; they are likely the result of developmental changes in cardiac energy metabolism, including mitochondrial function. The high resistance of the newborn heart cannot be further increased by ischemic preconditioning or adaptation to chronic hypoxia; these protective mechanisms appear only with decreasing tolerance during development. Resistance of the adult myocardium to acute oxygen deprivation may be significantly influenced by perinatal hypoxia. These results suggest that the developmental approach offers new possibilities in the studies of pathogenesis, prevention and therapy of critical cardiovascular diseases.
\end{abstract}

\section{Key words}

Hypoxia/ischemia • Cardiac tolerance • Ontogenetic development

- Cardiac protection

\section{Corresponding author}

B. Oštádal, Institute of Physiology AS CR, Vídeňská 1083, 14220

Prague 4, Czech Republic. E-mail: ostadal@biomed.cas.cz

\section{Introduction}

Hypoxia is the result of disproportion between the amount of oxygen supplied to the cardiac cell and the amount of oxygen necessary for covering its metabolic requirements. Theoretically, any of the known mechanisms leading to tissue hypoxia can be responsible for reduced oxygen supply in the myocardium but the most common cause is undoubtedly ischemic hypoxia (often described as "cardiac ischemia"), induced by reduction or interruption of the coronary blood flow and hypoxic (systemic) hypoxia, characterized by a drop in systemic $\mathrm{PO}_{2}$ in the arterial blood, but adequate perfusion. It should be emphasized that the terms "hypoxia" and "ischemia" are unfortunately often used interchangeably in the literature despite the fact that the consequences of the two mechanisms at the cellular level are very different. In ischemia there is not only a drop in the supply of oxygen and substrates, but also a significant reduction in the clearance of metabolites; their stepwise accumulation leads to the decrease of intracellular $\mathrm{pH}$ and to the development of hyperosmolarity. In contrast, in cardiac hypoxia, perfusion results in washing out of the acidic products of glycolysis, thereby retarding the rate of development of acidosis. Furthermore, systemic hypoxia is usually a generalized phenomenon diffusely involving the whole myocardium, whereas ischemia is confined to the area supplied by the affected coronary artery. With a reduction in oxygen supply, the adult as well as the immature myocardium switches from the aerobic to the anaerobic mode, and the capacity of the myocytes to generate energy in the form of ATP and creatine 
phosphate becomes severely reduced. Energy depletion, oxygen radical accumulation, loss of calcium homeostasis and loss of osmotic control lead to contractile dysfunction, membrane disruption and finally to death of the cardiac cell. The degree of myocardial injury depends, however, not only on the intensity and duration of hypoxic (ischemic) stimulus but also on the degree of cardiac sensitivity to oxygen deficiency. This particular parameter changes significantly during ontogeny. This is not surprising because most of the determinants of the relationship between myocardial oxygen supply and demand change markedly during development. For instance, early postnatal development is characterized by a rapid rate of coronary capillary formation: whereas in the newborn rat heart one capillary supplies 16 myocytes, at the end of the weaning period (day 28) only one cardiac cell (Rakusan 1999). Similarly, early after birth the cardiac performance of the rat heart also changes: index of contractility increases significantly until the weaning period, the rise is most expressed during the first postnatal week. These changes are very fast: e.g. contractile response to low extracellular sodium differs even day-by-day during the first week of life (Oštádalová et al. 1995).

Our present focus on the hypoxic immature heart is driven by clinical urgency: cyanotic congenital cardiac malformations remain the single largest cause of mortality from congenital defects and ischemic heart disease is no more the disease of the fifth and older decades but its origin as well as risk factors, such as genetic predisposition, hyperlipoproteinemia, smoking, hypertension, obesity and diabetes are present already during the early phases of the ontogenetic development (Fejfar 1975, Šamánek and Urbanová 2003). In a short survey we would like to summarize the current view on the three, very closely related, areas of research on the hypoxic immature heart: postnatal development of cardiac tolerance to oxygen deprivation, possibilities of protection and finally late effects of the early hypoxia. The review is based on our long experimental experience (Oštádal et al. 2009) with particular attention to the aspects studied in our laboratory.

\section{Postnatal development of cardiac tolerance to oxygen deprivation}

Early evidence for an age-dependent decrease in resistance to hypoxia is found in studies on the survival time of the rat, cat, dog, guinea pig, and rabbit in anoxic environments (Fazekas et al. 1941). It was found that in each species the survival time was inversely related to the age and to the maturity of the newborn. However, because these studies were performed in intact animals, effects of hypoxia on the central nervous system, peripheral resistance, and acid-base balance could affect myocardial function. The concept of greater tolerance of the neonatal heart has been supported by $\mathrm{Su}$ and Friedman (1973) and Jarmakani and co-workers (1978a,b, 1982). By using the perfused myocardium, they have shown that $30 \mathrm{~min}$ of anoxia had a minimum effect on myocardial function in the newborn rabbit and dogs; the effect of hypoxia on the contractile function was, in both species, inversely related to age. Moreover, the increase in lactate production during hypoxia was significantly greater in the newborn than in the adult, indicating that newborns are capable of maintaining adult levels of myocardial ATP. Similar age-dependent tolerance to hypoxia was observed in rats (Oštádal et al. 1982, Ošt'ádal et al. 1999): the resistance of the isolated right ventricle to anoxia was significantly higher in newborn males than in adults. The ontogenetic changes showed a biphasic pattern: the relatively high cardiac resistance at birth even increased up to the end of the weaning period in both male and female hearts; however, this value decreased in males from the 30th to the 60th day but remained unchanged in females. The adult female heart was thus significantly more resistant to hypoxia than the male heart.

As with hypoxia, the immature myocardium also appears to be relatively resistant to ischemia in the rabbit (Baker et al. 1988), pig (Baker et al. 1990), dog (Julia et al. 1990a), and rat (Riva and Hearse 1993). Riva and Hearse (1993) observed that the age-dependent changes in resistance to global ischemia in the isolated rat heart showed a biphasic pattern with increasing tolerance from 5 to 23 days of age, followed by a decline to adulthood. These observations were similar to our experiments on cardiac resistance to acute anoxia, mentioned above (Ošt'ádal et al. 1999). Detailed analysis of the tolerance of the isolated rat heart to global ischemia during the first week of life has, however, revealed a significant decrease from day 1 to day 7 (Oštádalová et al. 1998) (Fig. 1), suggesting a possible triphasic pattern of the ontogenetic development of cardiac sensitivity to ischemia. Similarly as in adulthood, the sensitivity of neonatal myocardium may be species-dependent; Baker et al. (1995) have shown that the neonatal pig heart is more susceptible to ischemia than the neonatal rabbit heart. 


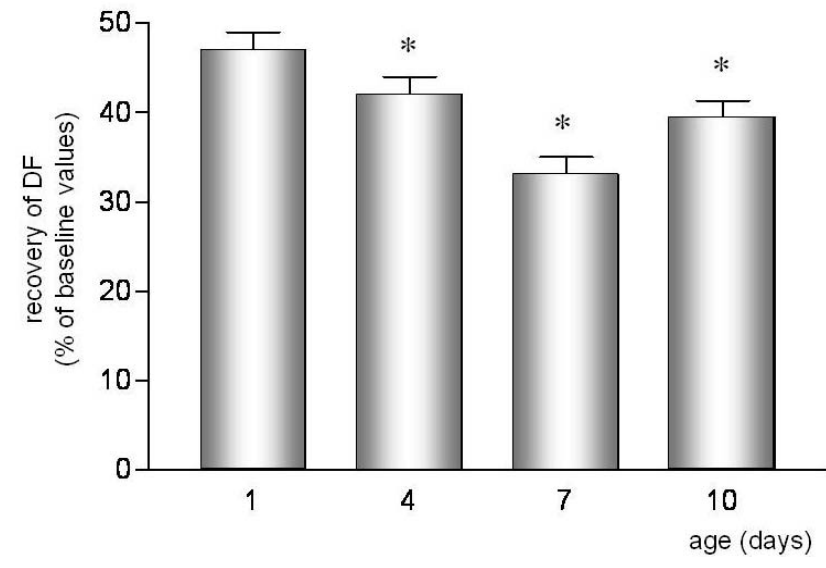

Fig. 1. Tolerance of the isolated perfused neonatal rat heart to acute ischemia (expressed as the recovery of the developed force - DF). * Statistically significant difference $(p<0.01)$ as compared with the first day of postnatal life. Data from Ošt'ádalová et al. (1998).

\section{Possible mechanisms of the higher tolerance of the immature heart to hypoxia/ischemia}

The mechanisms of the higher resistance of the immature heart to oxygen deprivation have not yet been satisfactorily clarified. For the explanation of this fact it should be taken into consideration that the fetus (and therefore also its heart) lives in the hypoxic environment, where $\mathrm{PO}_{2}$ is only $47 \mathrm{~mm} \mathrm{Hg}$, which corresponds to an altitude of $8000 \mathrm{~m}$ ("Mount Everest in utero"). The foetus is, however, well adapted: the prenatal period is characterized by polycytemia and fetal hemoglobin with the shift of the dissociation curve to the left. The major changes in oxygen saturation can be observed within delivery. During the short period of time the fetus (and its heart) comes from the hypoxic environment with low $\mathrm{PO}_{2}$ and low oxygen saturation (18\%) into the normal atmosphere $\left(\mathrm{PO}_{2} 160 \mathrm{~mm} \mathrm{Hg}\right.$, arterial saturation $\left.97 \%\right)$. The delivery is furthermore accompanied by the transition from the amniotic fluid to the air, by the marked decrease of the ambient temperature, by the termination of transplacental nutrition and by oxidative stress. Neonates face starvation until supply can be restored through milk nutrients. Kuma et al. (2004) have found that neonates adapt to these adverse circumstances by inducing autophagy, an intracellular degradation process in which a portion of cytoplasm is sequestered in an autophagosome and subsequently degraded upon fusion with a lysosome. They suggest that the production of amino acids by autophagic degradation of self proteins, which allows for the maintenance of energy homeostasis, is important for survival during neonatal starvation.
Autophagy in the mouse heart muscle is up-regulated during the early postnatal period: it is very low before birth, increases during the first three hours after delivery and gradually declines to the basal level by day one or two.

After birth, profound adaptive changes take place in the mammalian neonate, such as the onset of pulmonary circulation, transition from fetal to neonatal circulation, the switching-on of thermoregulation and a corresponding increase in basal metabolic rate. In this connection it is necessary to mention that during intrauterine life, the specific metabolic rate is still at the adult level (the fetus behaves "like an organ of its mother"), a more or less rapid increase in metabolic rate occurs after birth. The rate of postnatal metabolic increase depends on the maturity of the animal at birth, with mature neonates exhibiting a much faster metabolic increase than immature ones (Mühlfeld et al. 2005). However, under ischemic conditions, the decline in metabolic rate was much slower in neonatal than in adult hearts, matching the high tolerance of newborn animals to oxygen deprivation. The paradoxical increase in ischemia tolerance (as compared with adults) despite a higher tissue metabolic rate may be according to Mortola (2004) and Singer (2004) at least partly explained by the ability of neonatal tissue to temporarily go back to the fetomaternal metabolic level, thereby achieving a "hypoxic hypometabolism".

The reason of the higher cardiac tolerance during further postnatal development can be still only hypothetical. It may be speculated that an explanation of the phenomenon lies in the greater anaerobic glycolytic capacity, higher glycogen reserves of the immature heart (Hoerter 1976, Young et al. 1983) or amino acid utilization by transamination (Julia et al. 1990b). Moreover, the ATP catabolic pathways change during development (Hohl 1997); the immature heart is better equipped to ATP synthesis than to its breakdown, the situation that might be advantageous in conditions of low substrate availability. The immature heart thus suffers less ischemic injury after the same ischemic insult (Southworth et al. 1997). Another factor that may contribute to the increased tolerance of the immature heart is the age-related change in calcium handling (for review see Nijjar and Dhalla 1997). Calcium homeostasis is closely related to cell metabolism and is an accepted determinant of tissue injury during both oxygen deprivation and repletion. Calcium handling in the immature heart is different from that in the adult. The 
contraction of mammalian myocardium is known to depend on both transsarcolemmal calcium influx and calcium release from the sarcoplasmic reticulum (Fabiato 1983). However, the relative contribution of the two mechanisms varies significantly during development. The contraction of the immature myocardium where the sarcoplasmic reticulum is not fully developed depends to a large extent on the fluxes of calcium across the sarcolemma (Vetter et al. 1995). During further development, the ability of sarcoplasmic reticulum to accumulate and release calcium increases and, simultaneously, changes the distribution of the calcium channels of the sarcolemma (Wibo et al. 1991, 1995). Similarly, calcium sensitivity of cardiac myofilaments increases, reaching the adult values in rats starting from the 15th day of postnatal life (Vornanen 1997). An analogous developmental trend is found in the cardiac sensitivity to isoprenaline-induced calcium overload (Ošt’ádalová and Ošt'ádal 1994). Moreover, the immature heart is - as a consequence of a higher functional dependence on transsarcolemmal calcium influx - more sensitive to the negative inotropic effect of calcium antagonists: the dose which in the adult myocardium induced only a small negative inotropic effect stopped the contraction in the neonatal heart (Boucek et al. 1984, Škovránek et al. 1986, Koláŕ et al. 1990). For the explanation of this clinically relevant finding the calcium antagonist-induced shortening of the action potential and the decreased activity of natrium/calcium exchanger should be taken into consideration (Artman et al. 2002). An important role in the cardiac tolerance to oxygen deprivation may be played also by acidosis: the negative inotropic effect of low $\mathrm{pH}$ was strikingly smaller in the neonatal rabbits (Nakanishi et al. 1985) which, according to Solaro et al. (1988), can be accounted for by lower myofibrillar calcium sensitivity to low $\mathrm{pH}$ in this age group. None of these observations can, however, fully explain the day-by-day changes in cardiac tolerance to ischemia we have observed in rats during the first week of life (Ošt’ádalová et al. 1998).

\section{Potential role of mitochondria in the tolerance of the immature heart to oxygen deprivation}

The above mentioned studies suggest that the developmental decrease in cardiac tolerance is probably associated with substantial changes in energy metabolism: fetal and newborn hearts are relatively more dependent on anaerobic glycolysis whereas the mature myocardium is almost exclusively aerobic with fatty acids as the predominant substrate (Lopaschuk 1998, Bass et al. 2001). Still unclear is the role of mitochondria in the developmental changes in cardiac tolerance to oxygen deprivation in spite of the fact that mitochondria are responsible for cellular oxygen handling. Ontogenetic development of cardiac mitochondria is characterized by quantitative and qualitative changes: they increase in number, size and volume (Legato 1979, Olivetti et al. 1980). The heart thus seems to be equipped with the amount of mitochondria necessary to allow the postnatal metabolic increase; vice versa, the low mitochondrial volume fraction might limit depletion of oxygen stores under hypoxic conditions and thus contribute to the elevated myocardial ischemia tolerance in immature heart (Mühlfeld et al. 2005). Ultrastructural studies indicate that the originally chaotic organization of mitochondria and muscle fibres in the immature heart becomes gradually regular and two populations of mitochondria, subsarcolemmal and interfibrillar, typical of the adult myocardium, occur up to the weaning period (Ošt'ádal and Schiebler 1971). Mitochondrial oxidative phosphorylation is not completely developed in rat heart at birth; cardiac maturation during the first postnatal week is characterized by increasing content and specific activity of cytochrome $c$ oxidase and enhanced flux of adenine nucleotides across the inner mitochondrial membrane (Schagger et al. 1995, Schonfeld et al. 1996, Drahota et al. 2004). We have shown previously (Škarka et al. 2003) that the content of cytochromes in cardiac mitochondria increased two-fold between birth and day 30, similarly as the expression of adenine nucleotide translocase 1. Moreover, in newborn animals, a single population of mitochondria with relatively high mitochondrial membrane potential (MMP) was observed. Starting with the weaning period, a second population with significantly lower MMP occurs. Thus, in adults, a bimodal pattern of the MMP is found, suggesting two populations of cardiac mitochondria with different MMP; whereas two populations differing in MMP (high and low) were observed in subsarcolemmal fraction, in the interfibrillar fraction only a single high-MMP population was found. These results support the idea that the ontogenetic development of efficiency of mitochondrial energy conversion may be involved in the cardiac resistance to oxygen deprivation. However, the mechanisms that modulate the efficiency of mitochondrial function and might affect myocardial 
sensitivity to oxygen deprivation during ontogeny require further analysis.

The collapse of MMP due to the opening of a high conductance mitochondrial permeability transition pore (MPTP) in the inner mitochondrial membrane has been implicated in the molecular mechanism associated with ischemia/reperfusion (I/R) injury of the adult heart (Di Lisa and Bernardi 1998, 2006); conditions associated with post-ischemic reperfusion such as reactive oxygen species (ROS) accumulation, $\mathrm{pH}$ normalization and rise in intracellular calcium create an ideal situation for MPTP opening. MPTP opening is accompanied by matrix swelling, rupture of the outer membrane, and release of $\mathrm{NADH}$ and cytochrome $c$ which leads to the induction of myocardial cell death (Halestrap 2006). Initial support for the role of MPTP in I/R injury was provided by pharmacology: blockade of MPTP by cyclosporine A (CsA, Griffiths and Halestrap 1993) and sanglifehrin A (SfA, Clarke et al. 2002) in adult perfused heart was cardioprotective.

We have observed significant ontogenetic differences in the role of MPTP in the I/R injury (Milerová et al. 2009). Whereas the blockade of MPTP by SfA in perfused rat heart had a protective effect on I/R-induced damage in the adult myocardium as already demonstrated (Di Lisa et al. 2001, Clarke et al. 2002), it had no effect in the neonatal heart. For the explanation of this difference, several possibilities have to be taken into consideration: a modified amount of cyclophilin receptors in the neonatal heart or lower sensitivity of MPTP in the neonatal heart to pore opening factors. Another mechanism which may be involved in the developmental changes of cardiac resistance to $I / R$ injury is the mitochondrial content of cyclophilin $\mathrm{D}$, a protein considered to be involved in the mitochondrial permeability transition on the basis of the observation that CsA, a specific inhibitor of the cyclophilin family activity, blocks the MPTP. It was shown that cyclophilin $\mathrm{D}$ deficient mice were protected from I/R-induced cell death in vivo (Baines et al. 2005), as well as from oxidative stress and calcium overload (Nakagawa et al. 2005). Absence of the SfA inhibitory effect on $\mathrm{NAD}^{+}$ release from the neonatal heart could demonstrate that MPTP is not activated by $I / R$ injury to such an extent as in the adult heart. This suggests that the blockade with SfA cannot be used for evaluation of the MPTP function in the neonatal heart. For the analysis of the abovementioned problem it seems to be more suitable to measure the swelling of the isolated mitochondria as an indicator of pore opening (Balaska et al. 2005). We have found (Milerová et al. 2009) (Fig. 2) that in cardiac mitochondria isolated from neonatal rats, Ca-dependent and CsA-sensitive MPTP is less sensitive to $\mathrm{Ca}^{2+}$ ions as compared with adults. Since there are no data available on the possible developmental changes in the mechanism(s) of MPTP opening in the cardiac muscle, we can only speculate that its lower sensitivity to the calcium-induced swelling may be related to the higher ischemic tolerance of the neonatal heart. This idea supports the view that cardiac mitochondria, organelles responsible for cellular oxygen handling and energy production, are deeply involved in the regulation of cardiac tolerance to oxygen deprivation.

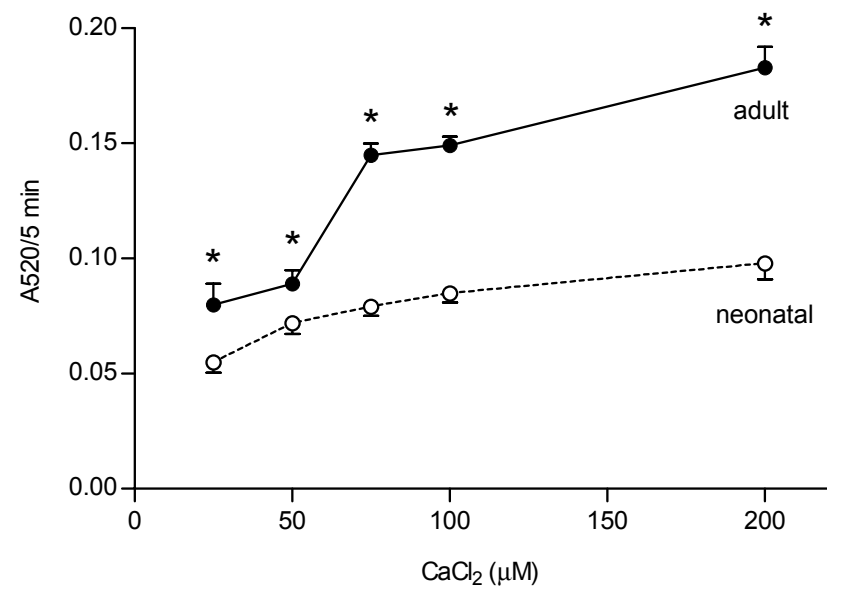

Fig. 2. The extent of mitochondrial swelling of heart mitochondria (determined as the decrease in absorbance at $520 \mathrm{~nm}$ ) from adult and neonatal (7-day-old) rats. * Statistically significant difference $(p<0.01)$ between both age groups. Data from Milerová et al. (2009).

\section{Protection of the immature heart}

As mentioned above, cardiac tolerance of the immature heart to oxygen deficiency is significantly higher as compared with the adult myocardium. Thus the question arises whether we can further increase the already high resistance of the immature heart. To the most effective experimental protective mechanisms belongs long-lasting adaptation to chronic hypoxia (for review see Ošt’ádal and Kolář 2007) and brief adaptation, so-called ischemic preconditioning (IP, for reviews see Yellon and Downey 2003, Bolli 2007). Data on the effects of these two phenomena on the immature cardiac muscle are, however, only sporadic. The protective effect of postconditioning (Vinten-Johansen 2007) is comparable with IP and was observed in many species 
including humans (Laskey 2005). Data on the possible effect of postconditioning on the immature heart are, however, still lacking.

\section{Ischemic preconditioning}

It is now 23 years since the phenomenon termed "ischemic preconditioning" has been formally recognized. In their seminal study, Murry et al. (1986) reported that infarct size produced by 40 min of sustained coronary occlusion could be markedly reduced if they first "preconditioned" the heart with four 5-min episodes of brief ischemia. Whereas extensive data are available on IP in the adult myocardium, information on whether this protective phenomenon also occurs in immature hearts is inadequate. We have shown (Ošt’ádalová et al. 1998) that classical IP, at least in rats, is not present at birth and that the enhanced postischemic recovery of contractile function can be observed only at the end of the first postnatal week. The decreasing tolerance of the neonatal heart to ischemia is thus counteracted by the development of the inducible endogenous protective mechanism. Awad et al. (1998) have shown that the absence of IP in immature isolated hearts cannot be overdriven by increasing the preconditioning stimulus. In addition, a pharmacological stimulus (phenylephrine) also failed to protect the immature heart.

Molecular mechanisms of IP in the adult myocardium are still unclear and the same is true for the immature heart. Signaling cascade obviously starts by the release of some "protective molecules" (for review see Yellon and Downey 2003). These molecules are able to bind to the receptors of cardiac cells coupled with G-proteins, thereby starting the activation of one or more signaling pathways; this finally leads to the phosphorylation of the target proteins (for review see Bolli 2007). The end-effector of this cascade might be e.g. the mitochondrial ATP dependent potassium $\left(\mathrm{K}_{\mathrm{ATP}}\right)$ channels (Garlid et al. 2003). Baker et al. (1999) have found that IP is associated with activation of mitochondrial $\mathrm{K}_{\mathrm{ATP}}$ channels even in the immature rabbit heart. On the other hand, in the immature rat heart the administration of 5-hydroxydecanoate, a selective blocker of the mitochondrial $\mathrm{K}_{\mathrm{ATP}}$ channels, had no effect on the protection by IP (Oštádalová et al. 2002). It seems, therefore, that in the mechanism of IP in the immature heart may exist significant interspecies differences. It remains unanswered, whether the mechanisms of IP, participating in the immature heart, differ from the mechanisms, described for the adult myocardium.
Adaptation to chronic hypoxia

Chronic hypoxia $(\mathrm{CH})$ is the main pathophysiological feature of hypoxemic congenital heart disease. Understanding the mechanisms by which cyanotic congenital heart malformations modify the myocardium and how the modifications impact on the cardiac tolerance to oxygen deprivation may provide insight into developing treatments for limiting myocardial damage. Unfortunately, no existing model adequately reproduces chronic myocardial perfusion with the hypoxic blood caused by congenital cyanotic defects. Therefore, similar experimental models as in adults, i.e. $\mathrm{CH}$ simulated in the normobaric or hypobaric chambers are used in studies performed during early stages of ontogenetic development.

Already in the late 1950s, the first observation appeared (Hurtado, 1960), showing that the incidence of myocardial infarction is lower in people living at high altitude. These epidemiological studies on the protective effect of high altitude were confirmed in experimental studies using simulated hypoxia (for review see Oštádal and Koláŕ 2007). However, only a few authors have compared tolerance to oxygen deprivation in chronically hypoxic versus normoxic immature myocardium. We have observed (Oštádal et al. 1995) that CH, simulated in the barochamber, results in similarly enhanced cardiac resistance in rats exposed to $\mathrm{CH}$ either from the 4th day of postnatal life or in adulthood. Similarly, Baker et al. (1995) demonstrated that adaptation to $\mathrm{CH}$ increased the tolerance of the developing rabbit heart. However, it follows from our results (Oštádalová et al. 2002) (Fig. 3) that the protective effect of $\mathrm{CH}$ is absent in newborn rats and the protective effect of adaptation develops similarly as that of IP - only during the first postnatal week. These results suggest that we might be dealing with the more general biological phenomenon: the already high resistance of the cardiac muscle cannot be further increased by different protective mechanisms. A similar situation as in the immature mammalian heart can be observed also in the highly tolerant hearts of poikilotherms or in the myocardium of young-adult females. In addition to protective effects, adaptation to $\mathrm{CH}$ also induces other adaptive responses including polycythemia, hypoxic pulmonary hypertension and right ventricular hypertrophy. The degree of these changes is comparable in animals exposed to $\mathrm{CH}$ after birth or in adulthood (Koláŕ et al. 1989, Ošt’́dal et al. 1995).

Molecular mechanisms of the cardioprotective effect of adaptation to $\mathrm{CH}$ have been much less studied 


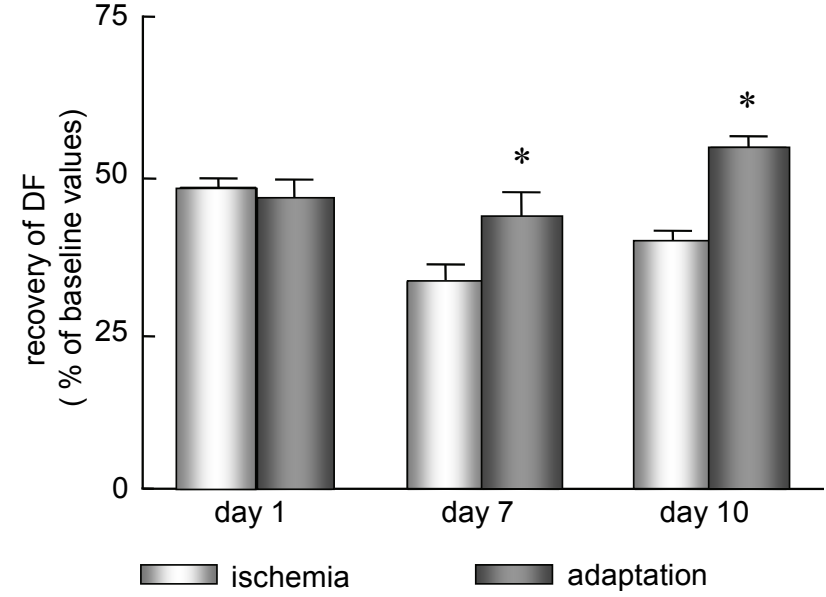

Fig. 3. Tolerance of the isolated perfused neonatal rat heart to acute ischemia (expressed as the recovery of the developed force - DF) in controls and in animals adapted to chronic hypoxia. * Statistically significant difference $(p<0.01)$ between both groups. Data from Oštádalová et al. (2002).

than in IP and the understanding of its signaling is still very limited (for review see Kolár̆ and Ošt’ádal 2004). Nevertheless, it seems that various protective phenomena including both short-lived IP and long-lasting effects of $\mathrm{CH}$, utilize essentially the same endogenous pool of protective pathways, even if with different efficiency (Neckář et al. 2002a,b). They include ATP dependent potassium channels, oxygen free radicals, NO, different protein kinases, opioids and erythropoietin; however, other factors cannot be excluded (Kolár̆ and Ošt'ádal 2004).

Overwhelming majority of studies, analyzing the possible mechanisms of cardiac adaptation to $\mathrm{CH}$, deals exclusively with the adult myocardium. We have shown previously (Oštádalová et al. 2002) that blockade of mitochondrial $\mathrm{K}_{\text {ATP }}$ channels with 5-hydroxydecanoate completely abolished the cardioprotective effect of adaptation to $\mathrm{CH}$ also in neonatal rats; a similar effect had the blockade of NO by using L-NAME. It seems, therefore, that - unlike in IP - both mitochondrial $\mathrm{K}_{\mathrm{ATP}}$ channels and NO may play an important role in the mechanism of adaptation of the neonatal heart to $\mathrm{CH}$. Recently, it has been shown that also angiotensin II is involved in the mechanisms of adaptation of the immature heart to $\mathrm{CH}$ : the chronic blockade of angiotensin II type 1 receptors $\left(\mathrm{AT}_{1}\right)$ by irbesartan completely abolished the cardioprotective effect of $\mathrm{CH}$ (Rakusan et al. 2007). The involvement of $\mathrm{AT}_{1}$ receptor pathway in the adaptive responses of the immature hearts to $\mathrm{CH}$ should be taken into consideration in the treatment of children suffering from cyanotic congenital heart disease.

\section{Effect of perinatal hypoxia on cardiac tolerance to acute ischemia in adults}

The number of patients undergoing surgery for congenital cyanotic defects is steadily increasing (Nollert et al. 1997). This group of patients is growing older and is approaching the age characterized by significantly increased risk of serious cardiovascular diseases, such as hypertension and ischemic heart disease. Therefore, it can be expected that more such patients will require diagnostic and therapeutic catheterization or cardiac surgery. Under these conditions, the question of the presumed cardiovascular impact of perinatal hypoxia will be of considerable importance. In this connection it is necessary to mention that metabolic adaptation to $\mathrm{CH}$ was observed in the myocardium of children with cyanotic congenital cardiac defects: we have observed significant reduction of aerobic capacity and activation of protective cascades (Šamánek et al. 1989) (Fig. 4).

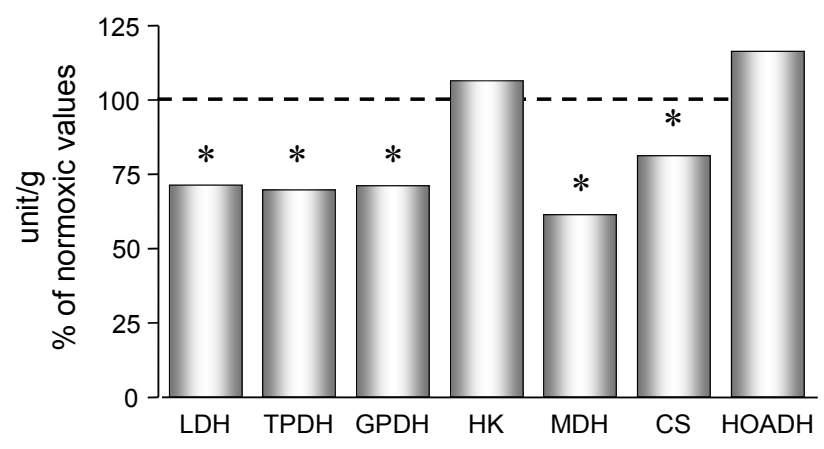

Fig. 4. Energy-supplying enzymes in the right atrium of children with tetralogy of Fallot and with normoxemic heart diseases (expressed as \% of normoxemic values). LDH - lactate dehydrogenase; TPDH - triosephosphate dehydrogenase; GPDH - glycerol-3-phosphate dehydrogenase; HK - hexokinase; MDH malate dehydrogenase; CS - citrate synthase; HOADH 3-hydroxyacyl-COA dehydrogenase. * Statistically significant difference $(p<0.01)$ from normoxemic values. Data from Šamánek et al. (1989).

Experimental studies on the late effects of $\mathrm{CH}$ on cardiac tolerance to hypoxia and ischemia is insufficient; moreover all of them have used exclusively males. Nevertheless, they have observed that perinatal hypoxia significantly increases the sensitivity of the adult rats to I/R injury (Li et al. 2003, Xu et al. 2006): the infarct size increased and the postischemic recovery of left ventricular function decreased as compared with the normoxic controls. Structural changes were accompanied by diastolic dysfunction of the left ventricle. We have shown (Netuka et al. 2006) that the late myocardial 
effects of hypoxemia, experienced in early life, may be sex dependent. Perinatal exposure to $\mathrm{CH}$ significantly increased cardiac tolerance to acute ischemic arrhythmias in adult females; the effect on arrhythmias in males was the opposite (Fig. 5).

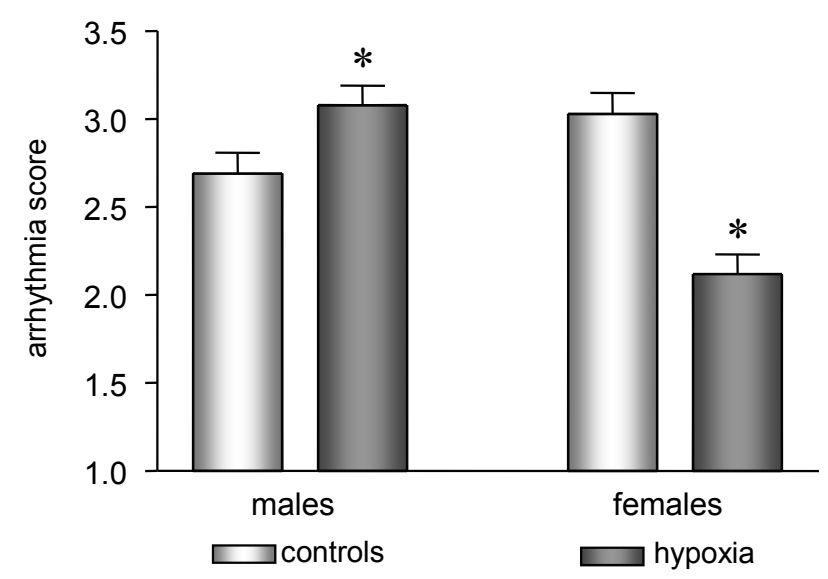

Fig. 5. Arrhytmia score over 30 min coronary artery occlusion in control and perinatally hypoxic adult male and female rats. Statistically significant difference $(p<0.01)$ between control and perinatally hypoxic group. Data from Netuka et al. (2006).

The precise molecular mechanism of the late effects of early hypoxia is still unknown. It seems, however, that perinatal hypoxia may cause in utero programming of several genes, including heat shock proteins (HSP 70), eNOS, $\beta$-adrenoceptors and G-proteins, which may have a long-lasting influence on cardiac function and play an important role in cardiac tolerance of the adult heart to ischemic injury (Snoeckx et al. 2001, Li et al. 2003). This opinion is supported, in part, by the finding (Li et al. 2004) that prenatal hypoxia results in an inhibition of the heat-stress induced increase in myocardial HSP 70 synthesis and abolishes heat-stress mediated cardioprotection in later adult life. There are no data available on possible sex differences in the mechanisms involved in the protective effect of adaptation to $\mathrm{CH}$ (for review see Ošt'ádal et al. 2009).

\section{Conclusions}

Developmental cardiology is now in the molecular era and new knowledge on the development of the cardiac muscle extends exponentially. It is, however, necessary to state that the interest of developmental cardiologists concentrates almost exclusively on the prenatal development; postnatal changes remain, unfortunately, neglected. It is yet obvious that the new methodological approaches, particularly molecular biology and genetics, can substantially help in the search for pathogenetic mechanisms involved during the whole ontogenetic development. Retrieval of developmental mechanisms participating on changes in cardiac tolerance to oxygen deprivation is the best example for this view.

\section{Conflict of Interest}

There is no conflict of interest.

\section{Acknowledgements}

This study was supported by grant MSMT 1M0510 and grant AVOZ 50110509.

\section{References}

ARTMAN M, MAHONY L, TEITEL DF: Regulation of myocyte contraction and relaxation. In: Neonatal Cardiology. M ARTMAN, L MAHONY, DF TEITEL (eds), McGraw Hill, New York, 2002, pp 19-38.

AWAD WI, SHATTOCK MJ, CHAMBERS DJ: Ischemic preconditioning in immature myocardium. Circulation 98: 206-213, 1998.

BAINES CP, KAISER RA, PURCELL NH, BLAIR NS, OSINSKA H, HAMBLETON MA, BRUNSKILL EW, SAYEN MR, GOTTLIEB RA, DORN GW, ROBBINS J, MOLKENTIN JD: Loss of cyclophilin D reveals a critical role for mitochondrial permeability transition in cell death. Nature 434: 658-662, 2005.

BAKER EJ, BOERBOOM LE, OLINGER GN, BAKER JE: Tolerance of the developing heart to ischemia: impact of hypoxemia from birth. Am J Physiol 268: H1165-H1173, 1995.

BAKER JE, BOERBOOM LE, OLINGER GN: Age-related changes in the ability of hypothermia and cardioplegia to protect ischemic rabbit myocardium. J Thorac Cardiovasc Surg 96: 717-724, 1988.

BAKER JE, BOERBOOM LE, OLINGER GN: Is protection of ischemic neonatal myocardium by cardioplegia species dependent. J Thorac Cardiovasc Surg 99: 280-287, 1990.

BAKER JE, HOLMAN P, GROSS GJ: Preconditioning in immature rabbit hearts. Role of $\mathrm{K}_{\mathrm{ATP}}$ channels. Circulation 99: 1249-1254, 1999. 
BALASKA D, HALESTRAP AP, SULEIMAN M-S, GRIFFITHS EJ: Increased susceptibility to pore-opening in heart mitochondria from neonatal compared with adult rats. (abstract). J Mol Cell Cardiol 38: 1002, 2005.

BASS A, STEJSKALOVÁ M, STIEGLEROVÁ A, OŠŤÁDAL B, ŠAMÁNEK M: Ontogenetic development of energy-supplying enzymes in rat and guinea-pig heart. Physiol Res 50: 237-245, 2001.

BOLLI R: Preconditioning: a paradigm shift in the biology of myocardial ischemia. Am J Physiol 292: H19-H27, 2007.

BOUCEK RJ, SHELTON M, ARTMAN M, MUSHLIN PS, STARNES VA, OLSON RD: Comparative effect of verapamil, nifedipine and diltiazem on contractile function in the isolated immature and adult rabbit heart. Pediatr Res 18: 948-954, 1984.

CLARKE SJ, MCSTAY GP, HALESTRAP AP: Sanglifehrin A acts as a potent inhibitor of the mitochondrial permeability transition and reperfusion injury of the heart by binding to cyclophilin-D at a different site from cyclosporin A. J Biol Chem 277: 34793-34799, 2002.

DI LISA F, BERNARDI P: Mitochondrial function as a determinant of recovery or death in cell response to injury. Mol Cell Biochem 184: 379-391, 1998.

DI LISA F, MENABO R, CANTON M, BARILE M, BERNARDI P: Opening of the mitochondrial permeability transition pore causes depletion of mitochondrial and cytosolic $\mathrm{NAD}^{+}$and is a causative event in the death of myocytes in postischemic reperfusion of the heart. J Biol Chem 276: 2571-2575, 2001.

DI LISA F, BERNARDI P: Mitochondrial function and myocardial aging. A critical analysis of the role of permeability transition. Cardiovasc Res 66: 222-232, 2006.

DRAHOTA Z, MILEROVÁ M, STIEGLEROVÁ A, HOUŠTĚK J, OŠŤÁDAL B: Developmental changes of cytochrome c oxidase and citrate synthase in rat heart homogenate. Physiol Res 53: 119-122, 2004.

FABIATO A: Calcium-induced release of calcium from the sarcoplasmic reticulum. Am J Physiol 245: C1-C14, 1983.

FAZEKAS JF, ALEANDER FAD, HIMWICH HE: Tolerance of the newborn to anoxia. Am J Physiol 134: 281-285, 1941.

FEJFAR Z: Prevention against ischaemic heart disease: a critical review. In: Modern Trends in Cardiology - 3. M.F. OLIVER (ed), Butterworths, London, 1975, pp 465-499.

GARLID KD, DOS SANTOS P, XIE ZJ, COSTA AD, PAUCEK P: Mitochondrial potassium transport: the role of the mitochondrial ATP-sensitive $\mathrm{K}^{+}$channel in cardiac function and cardioprotection. Biochim Biophys Acta 1606: 1-21, 2003.

GRIFFITHS EJ, HALESTRAP AP: Protection by cyclosporin A of ischemia/reperfusion-induced damage in isolated rat hearts. J Mol Cell Cardiol 25: 1461-1469, 1993.

HALESTRAP AP: Calcium, mitochondria and reperfusion injury: a pore way to die. Biochem Soc Trans 34: 232-237, 2006.

HOERTER J: Changes in the sensitivity to hypoxia and glucose deprivation in the isolated perfused rabbit heart during perinatal development. Pflugers Arch 363: 1-6, 1976.

HOHL CM: Effect of respiratory inhibition and ischemia on nucleotide metabolism in newborn swine cardiac myocytes. In: The Developing Heart. B OŠŤÁDAL, M NAGANO, N TAKEDA, NS DHALLA (eds), Lippincott, Philadelphia, 1997, pp 393-406.

HURTADO A: Some clinical aspects of life at high altitudes. Ann Intern Med 53: 247-258, 1960.

JARMAKANI JM, NAGAMOTO T, NAKAZAWA M, LANGER GA: Effect of hypoxia on mechanical function in the neonatal mammalian heart. Am J Physiol 235: H469-H474, 1978a.

JARMAKANI JM, NAGAMOTO T, NAKAZAWA M, LANGER GA: Effect of hypoxia on myocardial high-energy phosphates in the neonatal mammalian heart. Am J Physiol 235: H475-H481, 1978b.

JARMAKANI JM, NAKANISHI T, GEORGE BL, BERS D: Effect of extracellular calcium on myocardial mechanical function in the neonatal rabbit. Dev Pharmacol Ther 5: 1-13, 1982.

JULIA P, KORFSKY ER, BUCKBERG GD, YOUNG HH, BUGYI HI: Studies of myocardial protection in the immature heart. I. Enhanced tolerance of immature versus adult myocardium to global ischemia with reference to metabolic differences. J Thorac Cardiovasc Surg 100: 879-887, 1990a.

JULIA P, YOUNG PP, BUCKBERG GD, KORFSKY ER, BUGYI HI: Studies of myocardial protection in the immature heart. II. Evidence for importance of amino acid metabolism in tolerance to ischemia. $J$ Thorac Cardiovasc Res 100: 888-895, 1990 b. 
KOLÁŘ F, OŠŤÁDAL B, PROCHÁZKA J, PELOUCH V, WIDIMSKÝ J: Comparison of cardiopulmonary response to intermittent high-altitude hypoxia in young and adult rats. Respiration 56: 57-62, 1989.

KOLÁ ̌ F, OŠŤÁDAL B, PAPOUŠEK F: Effect of verapamil on contractile function of the isolated perfused heart. Basic Res Cardiol 85: 429-434, 1990.

KOLÁŘ F, OŠŤÁDAL B: Molecular mechanisms of cardiac protection by adaptation to chronic hypoxia. Physiol Res 53 (Suppl 1): S3-S13, 2004.

KUMA A, HATANO M, MATSUI M, YAMAMOTO A, NAKAYA H, YOSHIMORI T, OHSUMI Y, TOKUHISA T, MIZUSHIMA N: The role of autophagy during the early neonatal starvation period. Nature 432: 1032-1036, 2004.

LASKEY WK: Brief repetitive balloon occlusions enhance reperfusion during percutaneous coronary intervention for acute myocardial infarction; a pilot study. Catether Cardiovasc Interv 65: 361-367, 2005.

LEGATO MJ: Cellular mechanisms of normal growth in the mammalian heart. II. Qualitative and quantitative features of ventricular architecture in the dog from birth to live months of age. Circ Res 44: 263-279, 1979.

LI G, XIAO Y, ESTRELLA JL, DUCSAY CA, GILBERT RD, ZHANG L: Effect of fetal hypoxia on heart susceptibility to ischemia and reperfusion injury in the adult heart. J Soc Gynecol Investig 10: 265-274, 2003.

LI G, BAE S, ZHANG L: Effect of prenatal hypoxia on heat stress-mediated cardioprotection in adult rat heart. $A m J$ Physiol 286: 1712-1719, 2004.

LOPASCHUK GD: Treating ischemic heart disease by pharmacologically improving cardiac energy metabolism. Presse Med 27: 2100-2104, 1998.

MILEROVÁ M, CHARVÁTOVÁ Z, ŠKÁRKA L, OŠŤÁDALOVÁ I, DRAHOTA Z, FIALOVÁ M, OŠŤÁDAL B: Neonatal cardiac mitochondria and ischemia/reperfusion injury. Mol Cell Biochem 2009; in press.

MORTOLA JP: Implications of hypoxic hypometabolism during mammalian ontogenesis. Respir Physiol Neurobiol 141: 345-356, 2004.

MÜHLFELD C, SINGER D, ENGELHARDT N, RICHTER J, SCHMIEDL A: Electron microscopy and microcalorimetry of the postnatal rat heart (Rattus norvegicus). Comp Biochem Physiol A Mol Integr Physiol 141: 310-318, 2005.

MURRY CE, JENNINGS RB, REIMER KA: Preconditioning with ischemia: a delay of lethal cell injury in ischemic myocardium. Circulation 74: 1124-1136, 1986.

NAKAGAWA T, SHIMIZU S, WATANABE T, YAMAGUCHI O, OTSU K, YAMAGATA H, INOHARA H, KUBO T, TSUJIMOTO Y: Cyclophilin D-dependent mitochondrial permeability transition regulates some necrotic but not apoptotic cell death. Nature 434: 652-658, 2005.

NAKANISHI T, OKUDO H, NAKAZAWA M, TAKAO A: Effect of acidosis on contractile function in the newborn rabbit heart. Pediatr Res 19: 482-488, 1985.

NECKÁŘ J, PAPOUŠEK F, NOVÁKOVÁ O, OŠŤÁDAL B, KOLÁ̌̌ F: Cardioprotective effects of chronic hypoxia and ischaemic preconditioning are not additive. Basic Res Cardiol 97: 161-167, 2002.

NECKÁŘ J, SZÁRSZOI O, KOTEN L, PAPOUŠEK F, OŠŤÁDAL B, GROVER GJ, KOLÁŘ F: Effects of mitochondrial $\mathrm{K}_{\mathrm{ATP}}$ modulators on cardioprotection induced by chronic high altitude hypoxia in rats. Cardiovasc Res 55: 567-575, 2002.

NETUKA I, SZARSZOI O, MALÝ J, BEŠÍK J, NECKÁŘ J, KOLÁŘ F, OŠŤÁDALOVÁ I, PIRK J, OŠŤÁDAL B: Effect of perinatal hypoxia on cardiac tolerance to acute ischaemia in adult male and female rats. Clin Exp Pharmacol Physiol 33: 714-719, 2006.

NIJJAR MS, DHALLA NS: Biochemical basis of calcium handling in developing myocardium. In: The Developing Heart. B OŠŤÁDAL, M NAGANO, N TAKEDA, NS DHALLA (eds), Lippincott, Philadelphia, 1997, pp 189217.

NOLLERT G, FISCHLEIN T, BOUTERWEK S, BOHMER C, KLINNER W, REICHART B: Long-term survival in patients with repair of tetralogy of Fallot: 36-year follow-up of 490 survivors of the first year after surgical repair. J Am Coll Cardiol 30: 1374-1383, 1997.

OLIVETTI G, ANVERSA P, LOUD AV: Morphometric study of early postnatal development in the left and right ventricular myocardium of the rat. II. Tissue composition, capillary growth and sarcoplasmic alterations. Circ Res 46: 503-512, 1980. 
OŠŤÁDAL B, SCHIEBLER TH: Die terminale Strombahn in Herzen der Schildkröte (Testudo Hermanni). Z Anat Entwickl-Gesch 134: 111-116, 1971.

OŠŤÁDAL B, PROCHÁZKA J, JANATOVÁ T, PELOUCH V, KRAUSE EG: Developmental aspects of cardiac resistance to hypoxia. Ber Humboldt Univ Berlin 24: 52-58, 1982.

OŠŤÁDAL B, KOLÁŘ F, PELOUCH V, WIDIMSKÝ J: Ontogenetic differences in cardiopulmonary adaptation to chronic hypoxia. Physiol Res 44: 45-51, 1995.

OŠŤÁDAL B, OŠŤÁDALOVÁ I, DHALLA NS: Development of cardiac sensitivity to oxygen deficiency: comparative and ontogenetic aspects. Physiol Rev 79: 635-659, 1999.

OŠŤÁDAL B, KOLÁŘ F: Cardiac adaptation to chronic high altitude hypoxia. Respir Physiol Neurobiol 158: 224-236, 2007.

OŠŤÁDAL B, NETUKA I, MALÝ J, BEŠÍK J, OŠŤÁDALOVÁ I: Gender differences in cardiac ischemic injury and protection-experimental aspects. Exp Biol Med 234: 1011-1019, 2009.

OŠŤÁDAL B, CHARVÁTOVÁ Z, OŠŤÁDALOVÁ I, KOLÁŘ F, NETUKA I: Development of cardiac tolerance to oxygen deprivation - experimental aspects. (in Czech) Cor Vasa 51: 691-697, 2009.

OŠŤÁDALOVÁ I, OŠŤÁDAL B: Ontogenetic differences in isoproterenol-induced ${ }^{85} \mathrm{Sr}$ uptake in the myocardium. In: The Developing Heart. B OŠŤÁDAL, M NAGANO, N TAKEDA, NS DHALLA (eds), Lippincott, Philadelphia, 1997, pp 395-400.

OŠŤÁDALOVÁ I, OŠŤÁDAL B, KOLÁŘ F: Effect of prenatal hypoxia on contractile performance and responsiveness to $\mathrm{Ca}^{2+}$ in the isolated perinatal rat heart. Physiol Res 44: 135-137, 1995.

OŠŤÁDALOVÁ I, OŠŤÁDAL B, KOLÁŘ F, PARRATT JR, WILSON S: Tolerance to ischemia and ischaemic preconditioning in neonatal rat heart. J Mol Cell Cardiol 30: 857-865, 1998.

OŠŤÁDALOVÁ I, OŠŤÁDAL B, JARKOVSKÁ D, KOLÁŘ F: Ischemic preconditioning in chronically hypoxic neonatal rat heart. Pediatr Res 52: 561-567, 2002.

RAKUSAN K: Vascularization of the heart during normal and pathological growth. Adv Org Biol 7: 130-153, 1999.

RAKUSAN K, CHVOJKOVA Z, OLIVIERO P, OSTADALOVA I, KOLAR F, CHASSAGNE C, SAMUEL J-L, OSTADAL B: ANG II type 1 receptor antagonist irbesartan inhibits coronary angiogenesis stimulated by chronic intermittent hypoxia in neonatal rats. Am J Physiol 292: H1-H8, 2007.

RIVA A, HEARSE DJ: Age-dependent changes in myocardial succeptibility to ischemic injury. Cardioscience 4: 8592, 1993.

ROHLICEK CV, VIAU S, TRIEU P, HÉBERT TE: Effects of neonatal hypoxia in the rat on inotropic stimulation of the adult heart. Cardiovasc Res 65: 861-868, 2005.

SCHAGGER H, NOACK H, HALANGK W, BRANDT U, VON JAGOW G: Cytochrome c oxidase in developing rat heart. Enzymic properties and amino-terminal sequences suggest identity of the fetal heart and the adult liver isoform. Eur J Biochem 230: 235-241, 1995.

SCHONFELD P, SCHILD L, BOHNENSACK R: Expression of the ADP/ATP carrier and expansion of the mitochondrial (ATP+ADP) pool contribute to postnatal maturation of the rat heart. Eur J Biochem 241: 895900, 1996.

SINGER D: Metabolic adaptation to hypoxia: cost and benefit of being small. Respir Physiol Neurobiol 141: 215-228, 2004.

SNOECKX LH, CORNELUSSEN RN, VAN NIEUWENHOVEN FA, RENEMAN RS, VAN DER VUSSE GJ: Heat shock proteins and cardiovascular pathophysiology. Physiol Rev 81: 1461-1497, 2001.

SOLARO RJ, LEE JA, KENTISH JC, ALLEN DG: Effect of acidosis on ventricular muscle from adult neonatal rats. Circ Res 63: 779-787, 1988.

SOUTHWORTH R, SHATTOCK MJ, KELLY FJ: Age-related difference in the cardiac response to ischemia and free radical production on reperfusion. In: The Developing Heart. B OŠŤÁDAL, M NAGANO, N TAKEDA, NS DHALLA (eds), Lippincott, Philadelphia, 1997, pp 427-441.

SU JY, FRIEDMAN WF: Comparison of the responses of fetal and adult cardiac muscle to hypoxia. Am J Physiol 224: 1249-1253, 1973.

ŠAMÁNEK M, BASS A, OŠŤÁDAL B, HUČÍN B, STEJSKALOVÁ M: Effect of hypoxaemia on enzymes supplying myocardial energy in children with congenital heart disease. Int J Cardiol 25: 265-270, 1989. 
ŠAMÁNEK M, URBANOVÁ Z: Prevention of Atherosclerosis in Children. (in Czech) Galén, Praha, 2003, 226 p.

ŠKÁRKA L, BARDOVÁ K, BRAUNER, FLACHS P, JARKOVSKÁ D, KOPECKÝ J, OŠŤÁDAL B: Expression of mitochondrial uncoupling protein 3 and adenine nucleotide translocase 1 genes in developing rat heart: putative involvement in control of mitochondrial membrane potential. J Mol Cell Cardiol 35: 321-330, 2003.

ŠKOVRÁNEK J, OŠŤÁDAL B, PELOUCH V, PROCHÁZKA J: Ontogenetic differences in cardiac sensitivity to verapamil in rats. Pediatr Cardiol 7: 25-29, 1986.

VETTER R, STUDER R, REINECKE H, KOLÁŘ F, OŠŤÁDALOVÁ I, DREXLER H: Reciprocal changes in the postnatal expression of the sarcolemmal $\mathrm{Na}^{+}-\mathrm{Ca}^{2+}$-exchanger and SERCA2 in rat heart. J Mol Cell Cardiol 27: 1689-1701, 1995.

VINTEN-JOHANSEN J: Postconditioning: a mechanical maneuver that triggers biological and molecular cardioprotective responses to reperfusion Heart Fail Rev 12: 235-244, 2007.

VORNANEN M: Postnatal changes in cardiac calcium regulation. In: The Developing Heart. B OŠŤÁDAL, M NAGANO, N TAKEDA, NS DHALLA (eds), Lippincott, Philadelphia, 1997, pp 219-229.

WIBO M, BRAVO G, GODFRAIND T: Postnatal maturation of excitation-contraction coupling in rat ventricle in relation to the subcellular localization and surface density of 1,4-dihydropyridine and ryanodine receptors. Circ Res 68: 662-673, 1991.

WIBO M, KOLÁŘ F, ZHENG L, GODFRAIND T: Influence of thyroid status on postnatal maturation of calcium channels, $\beta$-adrenoceptors and cation transport ATPases in rat ventricular tissue. J Mol Cell Cardiol 27: 1731$1743,1995$.

XU Y, WILLIAMS SJ, O'BRIEN D, DAVIDGE ST: Hypoxia or nutrient restriction during pregnancy in rats leads to progressive cardiac remodeling and impairs postischemic recovery in adult male offspring. FASEB J 20: 12511253, 2006.

YELLON DM, DOWNEY JM: Preconditioning the myocardium: from cellular physiology to clinical cardiology. Physiol Rev 83: 1113-1151, 2003.

YOUNG HH, SHIMIZU T, NISHIOKA K, NAKANISHI T, JARMAKANI JM: Effect of hypoxia and reoxygenation on mitochondrial function in neonatal myocardium. Am J Physiol 245: H998-H1006, 1983. 